\title{
Effect of Self-Compassion Intervention Based on a Religious Perspective on the Anxiety and Quality of Life of Infertile Women: A quasi-experimental study
}

Yasser Rezapour-Mirsaleh ( $\nabla$ y.rezapour@ardakan.ac.ir)

Ardakan University https://orcid.org/0000-0002-7308-6912

Fatemeh Abolhasani

Ardakan University

Raziyeh Amini

Ardakan University

Azadeh Choobforoushzadeh

Ardakan University

Sepideh Masoumi

Ardakan University

Leila Shameli

Salman Farsi University of Kazerun

Research

Keywords: Compassionate Use Trials, Religion, Anxiety, Quality of Life, Infertility

Posted Date: April 29th, 2020

DOl: https://doi.org/10.21203/rs.3.rs-25046/v1

License: (c) (1) This work is licensed under a Creative Commons Attribution 4.0 International License.

Read Full License 


\section{Abstract}

Background Anxiety is one of the common psychological problems among infertile women, which affects their quality of life. The purpose of this study was to determine the effect of self-compassion intervention based on religious perspective on the anxiety and quality of life of infertile women.

Methods A qusai-experimental design with experimental and control groups was used. 24 women who lived in Maybod city, Iran, and were referred to Yazd reproductive sciences institute selected by available sampling and randomly assigned to experimental and control groups. The participants of experimental group received 8 sessions self-compassion focused intervention based on religious instructions and control group was put on the waiting list. Data were collected using Quality of Life Questionnaire in Infertile Couples Questionnaire (QOLICQ) and Beck anxiety inventory (BDI) in pretest and posttest phase and then analyzed using multivariate analysis covariance (MANCOVA).

Results The results showed as compared to control group at the post-test phase, the quality of life ( $\mathrm{p}<$ $.001)$ and anxiety $(p<.001)$ of infertile women increased and decreased, respectively, in the experimental group.

Conclusion Infertility medical centers can use self-compassion intervention based on a religious approach as a complementary psychological intervention, alongside with medical interventions, to improve the quality of life and reduce anxiety in infertile women.

\section{Introduction}

In many cultures, family formation and parenting is a value. However, many couples face the challenges of infertility in their lives. According to the World Health Organization (WHO), infertility defined as failure of conception in couples when they have been sexually active for 12 months or more without the use of contraceptives [1]. Infertility is most often accompanied by psychological stress. Based on previous studies, it can be concluded that infertile women have more psychological distress compared to the fertile peers [2, 3]. Also, findings from previous research show that depression and anxiety are two of the most common mental health problems in infertile women $[4,5]$, which may result in poor quality of life.

Poor quality of life and anxiety in infertile women may affect their treatment process. Findings of one study showed that 65 percent of physicians believed that anxiety had a negative effect on fertility. Interestingly, most physicians felt that fertility was affected by stress, anxiety and depression [6]. However, women quality of life if does not affect their fertility will probably affect their motivation to continue the treatment process [7]. Therefore, psychological interventions that can reduce stress, anxiety and depression and improve quality of life may have a positive effect on treatment of infertile women. One of these psychological interventions is self-compassion therapy. Because infertility causes women to have negative and self-critical feelings about themselves [3], self-compassion based therapy can help them to reduce these feelings. 
Self-compassion based therapy can help individuals face unhappy life events. Self-compassion involves being kind to oneself in failures and understanding of negative experiences as part of a great human experience [8]. Compassion and forgiveness turn negative feelings such as revenge, hatred and distress into positive emotions, such as peace, benevolence and empathy. Compassion leads to appreciation, moderation and hope [9]. Self-compassion consists of three main factors: 1 . Self-kindness, which refers to the desire to kindness toward self rather than self-criticism when facing personal dilemma and problems; 2 . The common humanity that refers to recognizing failure, problems, and stress as a normal part of human life; 3 ) mindfulness which refers to an awareness and distinction between thought and emotion and living in here and now [10]. Self-Compassion may act as a self-healing function that allows individuals to meet their own personal needs as valuable as others needs [11]. Therefore, the key goal of self-compassion interventions is to provoke positive emotions and reduce self-criticism and negative emotions [12]. Self-compassion leads to oxytocin stimulation, cortisol and cardiac parasympathetic depletion, and physiological reactions such as decreased heart rate $[13,14]$.

Religious schools, especially Islamic viewpoints, emphasize on self-compassion as a value. Selfcompassion is associated with religious orientation and can lead to improving mental health [15]. Evidence show that compassion as a religious value can decrease aggression in adolescents [16]. According to Muslims beliefs, compassion means getting to know human limitations, knowing that humankinds may make mistakes and they sometimes required to forgive themselves [17]. In Islam, compassion manifests itself in behaviors such as zakat (i.e. sharing wealth), attending to the affairs of relatives, neighbors and poor families, attending to the needs of parents, and many other recommended religious behaviors [17]. According to Islamic views, God is compassionate towards human beings and therefore humans should not blame themselves for problems that went beyond their will. God wants the best for human and every problem in life may have a purpose and expedient.

Many studies have examined the relationship between religious concepts and self-compassion components, but so far few studies have examined the impact of self-compassion intervention based on Islamic teachings. The findings of a recent study showed that compassionate therapy adapted to Islamic teachings than general compassion therapy, had a greater effect on reducing the self-compassion of cancer patients [18].

Considering the fact that Iran society dominated by Muslims, it is important to pay attention to Islam in psychological interventions. Regarding that compassion focused therapy can potentially be combined with religious viewpoints, self-compassion intervention based on religious instructions can be considered as an effective intervention for individuals who have an unresolved problem in life. Therefore, selfcompassion focused therapy based on religious perspectives may be considered a successful psychological intervention for Muslim women to deal with the problems of infertility. However, so far a few study attempted to combine compassionate therapy with religious viewpoints; Most of them were descriptive as well. No study was found to evaluate the effectiveness of self-compassion intervention based on religious perspective in infertile women; there was only one study in which the participants were 
cancer patients. so the purpose of this study was to evaluate the impact of self-compassion intervention based on a religious perspective on the anxiety and quality of life in infertile women.

\section{Materials And Methods}

This study was a qusai-experimental design with experimental and waiting list control groups. The statistical population of this study included all infertile women who lived in Maybod city, Iran, in 2017 and were referred to Yazd reproductive sciences institute. Infertility was diagnosed by a gynecologist. 24 women selected by available sampling and simple randomly assigned to experimental and control groups. Sample size was calculated using following formula based on 3 standard deviation for each group [19], 80\% power and expecting to get at least 2.5 difference score (One sample was selected for the probability of further decline):

$$
\mathrm{n}=\frac{(\mathrm{z}(1-\alpha / 2)+\mathrm{z}(1-\beta))^{2} \times\left(S_{1}^{2}+S_{2}^{2}\right)}{d^{2}}=\frac{(1.96+.84)^{2} \times\left(3^{2}+3^{2}\right)}{2.5^{2}}=22.6
$$

Inclusion criteria were as follow: 1- inclination to participate in the study, 2- women who passed at least 5 year from the infertility, 3 . receiving infertility treatment for at least 3 years, 4 . the age range of $25-$ 40 years old, 5 . having an Islamic religious orientation, 6) having at least school education. Exclusion criteria were as: 1 . having a specific mental and personality disorder, 2 . Taking psychiatric drugs, 3 . receiving other psychological treatments. These criteria were confirmed by referring to patients' medical records, clinical interview, and the Minnesota multiphasic personality inventory results. In order to control some of the intervening variables, participants in both groups were matched in terms of demographic variables such as age, duration of marriage, duration of treatment, and educational level. All participants suffered from female infertility, primary infertility and were treating by IVF method.

\section{Data Collection}

The participants of experimental group received 8 sessions self-compassion focused intervention based on religious instructions and control group was put on the waiting list. However, the control group continued its usual treatments at the Institute of Reproductive Sciences and was given explanations of the challenges of infertility as placebo. Intervention sessions were scheduled on days when control group participants were not exposed to the experimental group so that their possible interaction with each other did not affect the results of the study. Because the participants were resident in Maybod City, intervention sessions were held in the Ziai Consulting Center's meeting room in Maybod. However, Institute of Reproductive Sciences had only the role of introducing the subjects, and because the focus of treatment at the institute was on medical treatment, it was preferred that intervention sessions be held elsewhere. The content of the sessions was derived from similar studies $[12,20]$ and was enriched using Islamic sources according to the guidelines of each session (Table 1). Intervention was conducted by second author who had master in family counseling and had certificated in compassion therapy courses. Homework was reminded at the end of each session and reviewed at the beginning of the next session. 
Data were collected using quality of life questionnaires and Beck anxiety inventory in pretest and posttest. The study was conducted at November 2018-February 2019. Intervention flow-chart is presented in figure $\mathrm{I}$. 
Table 1

Content of Sessions

\begin{tabular}{|c|c|c|c|c|}
\hline & Aims & Content & Homework & Expectations \\
\hline $\begin{array}{l}\text { Session } \\
1\end{array}$ & $\begin{array}{l}\text { general } \\
\text { introduction } \\
\text { and review of } \\
\text { self- } \\
\text { compassion }\end{array}$ & $\begin{array}{l}\text { Initial communication, } \\
\text { Introducing group rules, Explain } \\
\text { the general principles of } \\
\text { compassion therapy, talk about } \\
\text { compassion as a religious value, } \\
\text { Avoiding to self-blame for } \\
\text { infertility, looking at infertility as } \\
\text { a destiny and God's will, Thinking } \\
\text { about oneself, the world, and the } \\
\text { system of creation and the } \\
\text { Creator and examples of God's } \\
\text { grace }\end{array}$ & $\begin{array}{l}\text { Search for } \\
\text { other life } \\
\text { situations that } \\
\text { we cannot } \\
\text { change }\end{array}$ & $\begin{array}{l}\text { Self-awareness, } \\
\text { self- } \\
\text { forgiveness }\end{array}$ \\
\hline $\begin{array}{l}\text { Session } \\
2\end{array}$ & $\begin{array}{l}\text { Introduction } \\
\text { components of } \\
\text { self- } \\
\text { compassion } \\
\text { Mindful self- } \\
\text { compassion, } \\
\text { Empathy with } \\
\text { others }\end{array}$ & $\begin{array}{l}\text { Introducing components of self- } \\
\text { compassion, Investigating status } \\
\text { of each component of } \\
\text { compassion in the participants } \\
\text { and its behavioral implications, } \\
\text { review of religious instructions in } \\
\text { compassionate behaviors, look } \\
\text { at the companionate behaviors } \\
\text { of prophet Mohammad, } \\
\text { presenting moment awareness } \\
\text { during the events, empathy with } \\
\text { others (i.e. mothers with children } \\
\text { with disability) }\end{array}$ & $\begin{array}{l}\text { Writing self- } \\
\text { compassion } \\
\text { components in } \\
\text { daily activities, } \\
\text { Mindfulness in } \\
\text { religious } \\
\text { practices, } \\
\text { Engaging with } \\
\text { people who } \\
\text { have } \\
\text { unresolved } \\
\text { problems }\end{array}$ & $\begin{array}{l}\text { Mindful self- } \\
\text { compassion, } \\
\text { compassionate } \\
\text { behaviors } \\
\text { based on } \\
\text { religious } \\
\text { instructions }\end{array}$ \\
\hline $\begin{array}{l}\text { Session } \\
3\end{array}$ & $\begin{array}{l}\text { Self- } \\
\text { awareness, } \\
\text { Acceptance of } \\
\text { self and others }\end{array}$ & $\begin{array}{l}\text { Become aware of his own } \\
\text { motives and attitudes about } \\
\text { childbearing, Mindful self- } \\
\text { awareness, evaluating self as a } \\
\text { "compassionate" or "non- } \\
\text { compassionate" person, Thinking } \\
\text { about self and life as a } \\
\text { religiously recommended } \\
\text { behavior, look at the literal root of } \\
\text { Islam means peace, friendship, } \\
\text { and "submission to the will of } \\
\text { God", acceptance self and } \\
\text { acceptance of life and others as } \\
\text { they are }\end{array}$ & $\begin{array}{l}\text { Identifying } \\
\text { Self- } \\
\text { Compassion } \\
\text { Barriers in } \\
\text { acceptance of } \\
\text { infertility, } \\
\text { Reporting the } \\
\text { number of self- } \\
\text { compassionate } \\
\text { versus non } \\
\text { self- } \\
\text { compassionate } \\
\text { behaviors }\end{array}$ & $\begin{array}{l}\text { Increased } \\
\text { sensitivity to } \\
\text { the behaviors } \\
\text { of self and } \\
\text { others based } \\
\text { on self- } \\
\text { compassion } \\
\text { factors, have a } \\
\text { self- } \\
\text { compassionate } \\
\text { mind }\end{array}$ \\
\hline $\begin{array}{l}\text { Session } \\
4\end{array}$ & $\begin{array}{l}\text { Compassion } \\
\text { Techniques, } \\
\text { Religious } \\
\text { manifestation } \\
\text { in } \\
\text { compassionate } \\
\text { behavior }\end{array}$ & $\begin{array}{l}\text { Accepting mistakes, describing } \\
\text { self-compassionate caring } \\
\text { stories, Writing a self- } \\
\text { compassionate letter, Islam's } \\
\text { emphasis on forgiveness as a } \\
\text { manifestation of compassion, } \\
\text { relation between repentance and } \\
\text { self-forgiveness in Islam, self- } \\
\text { love meditations, Self-love as a } \\
\text { way to reach God's love, self- } \\
\text { compassionate inner voice }\end{array}$ & $\begin{array}{l}\text { Applying } \\
\text { compassion } \\
\text { techniques and } \\
\text { religious } \\
\text { forgiveness in } \\
\text { daily life }\end{array}$ & $\begin{array}{l}\text { Become Skillful } \\
\text { in self- } \\
\text { compassion } \\
\text { techniques } \\
\text { according to } \\
\text { religious } \\
\text { perspective }\end{array}$ \\
\hline
\end{tabular}




\begin{tabular}{|c|c|c|c|c|}
\hline & Aims & Content & Homework & Expectations \\
\hline $\begin{array}{l}\text { Session } \\
5\end{array}$ & $\begin{array}{l}\text { living in } \\
\text { accordance } \\
\text { with core } \\
\text { values and } \\
\text { religious } \\
\text { beliefs, self- } \\
\text { care }\end{array}$ & $\begin{array}{l}\text { Review of core values and beliefs } \\
\text { of the participants, Considering } \\
\text { self-compassion as a core value, } \\
\text { living in accordance with } \\
\text { religious beliefs about how to } \\
\text { treat oneself and others, dealing } \\
\text { with destructive self-critical } \\
\text { tendencies, self-care against } \\
\text { shame and guilt, sympathy for } \\
\text { himself, self-harm as a religious } \\
\text { guilt }\end{array}$ & $\begin{array}{l}\text { Self-care as a } \\
\text { religious } \\
\text { practice, } \\
\text { Coping with } \\
\text { self-destructive } \\
\text { beliefs }\end{array}$ & $\begin{array}{l}\text { Compassionate } \\
\text { Self-Care in } \\
\text { daily life }\end{array}$ \\
\hline $\begin{array}{l}\text { Session } \\
6\end{array}$ & $\begin{array}{l}\text { deal with } \\
\text { difficult } \\
\text { emotions, } \\
\text { Accepting the } \\
\text { self despite } \\
\text { difficult } \\
\text { emotions }\end{array}$ & $\begin{array}{l}\text { Acceptance of positive and } \\
\text { negative emotions, } \\
\text { Nonjudgmental acceptance of } \\
\text { the self, Mindful emotion } \\
\text { regulation and appropriate } \\
\text { coping with difficult emotions, } \\
\text { Accompanying life and pain in } \\
\text { religious view; Life with pain } \\
\text { means a life with greatness and } \\
\text { Living with pain is a way of } \\
\text { approaching to God }\end{array}$ & $\begin{array}{l}\text { Emotion } \\
\text { regulation with } \\
\text { self- } \\
\text { compassion } \\
\text { manner in daily } \\
\text { life, } \\
\text { acceptance of } \\
\text { pains with } \\
\text { religious view }\end{array}$ & $\begin{array}{l}\text { deal with } \\
\text { difficult } \\
\text { emotions with } \\
\text { self- } \\
\text { compassion } \\
\text { manner }\end{array}$ \\
\hline $\begin{array}{l}\text { Session } \\
7\end{array}$ & $\begin{array}{l}\text { dealing with } \\
\text { challenging } \\
\text { interpersonal } \\
\text { relationships, } \\
\text { Acceptance of } \\
\text { others }\end{array}$ & $\begin{array}{l}\text { Recognizing that others also } \\
\text { have same or different problems } \\
\text { (shared human condition), } \\
\text { Unconditional acceptance of } \\
\text { others, talk about Islam's } \\
\text { emphasis on avoiding prejudice } \\
\text { to others and empathy with } \\
\text { others, Congregational religious } \\
\text { practices for closing to others }\end{array}$ & $\begin{array}{l}\text { Reviewing } \\
\text { others' } \\
\text { behaviors, } \\
\text { empathy with } \\
\text { them and } \\
\text { relate closely } \\
\text { with them }\end{array}$ & $\begin{array}{l}\text { Appropriate } \\
\text { behavior with } \\
\text { others despite } \\
\text { their mistakes }\end{array}$ \\
\hline $\begin{array}{l}\text { Session } \\
8\end{array}$ & $\begin{array}{l}\text { acceptance of } \\
\text { unchangeable } \\
\text { circumstances, } \\
\text { self- } \\
\text { acceptance } \\
\text { and live with } \\
\text { appreciation }\end{array}$ & $\begin{array}{l}\text { Acceptance of problems, } \\
\text { possible future changes, } \\
\text { acceptance and tolerance of } \\
\text { difficult conditions, Teaches } \\
\text { skills to live with appreciation, } \\
\text { hope for the future as a God's } \\
\text { command, A sense of self-worth } \\
\text { and appreciate value of life, } \\
\text { Confidence in the knowledge and } \\
\text { expediency of God in her } \\
\text { infertility }\end{array}$ & $\begin{array}{l}\text { Writing the } \\
\text { positive } \\
\text { changes made } \\
\text { in life as a } \\
\text { result of self- } \\
\text { compassion," } \\
\text { Find meaning } \\
\text { in self- } \\
\text { forgiveness }\end{array}$ & $\begin{array}{l}\text { Self-value, Self- } \\
\text { compassion, } \\
\text { Find meaning } \\
\text { in infertility, } \\
\text { Unconditional } \\
\text { self-acceptance }\end{array}$ \\
\hline
\end{tabular}

\section{Instruments}

\section{Demographic variables}

Demographic variables such as age, education and religious orientation (both in wife and husband), marriage duration, treatment duration, type of infertility and type of treatment were assessed using a profile form completed by infertile women. 
Quality of Life Questionnaire in Infertile Couples Questionnaire (QOLICQ): QOLICQ is a 72-item self-report questionnaire utilizes a 5 -point Likert-type scale $(1=$ completely agree, $5=$ completely disagree) which assess the quality of life of infertile couples. QOLICQ divided into 7 subscales as: 1- Physical health, 2Mental health, 3- Spiritual and religious beliefs, 4- Economic, 5- Emotional health, 6. Sexual Satisfaction, 7. Social Relationships. Validity and reliability of the QOLICQ was confirmed in an Iranian samples [21].

\section{Beck Anxiety Inventory (BAl)}

BAl is a 21-item self-report tool designed to measure the severity of generalized anxiety symptom in adolescents and adults [22]. Responses are based on a 4-point Likert scale ranging from 0 (not at all) to 3 (severely). Validity and reliability of Persian version of BAI was confirmed [23].

\section{Statistical Analysis}

Data analyzed by multivariate analysis covariance (MANCOVA) using statistical package for social science (SPSS, version 21.0) at the $p<.05$ level of statistical significance. Presumptions of MANCOVA include normal distribution of scores and normality homogeneity of variances of groups analyzed by Kolmogorov-Smirnov and levene's test respectively. Also, the independent sample t-test was used to compare groups in pretest and some demographic variables.

\section{Results}

Mean and standard deviation of demographic variables include age, duration of marriage and duration of treatment presented in Table 2.

Table 2

Mean and standard deviation of demographic variables

\begin{tabular}{|c|c|c|c|}
\hline Variable & Group & $M \pm S D$ & P value \\
\hline \multirow[t]{2}{*}{ age } & Exp & $31.83 \pm 4.17$ & \multirow[t]{2}{*}{$P>.05$} \\
\hline & Con & $31.5 \pm 3.71$ & \\
\hline \multirow[t]{2}{*}{ Marital Duration } & Exp & $9.66 \pm 4.03$ & \multirow[t]{2}{*}{$P>.05$} \\
\hline & Con & $9.67 \pm 3.63$ & \\
\hline \multirow[t]{2}{*}{ Treatment Duration } & Exp & $7.42 \pm 3.12$ & \multirow[t]{2}{*}{$P>.05$} \\
\hline & Con & $7.40 \pm 2.61$ & \\
\hline \multirow[t]{2}{*}{ Husband's age } & Exp & $35.06 \pm 3.91$ & \multirow[t]{2}{*}{$P>.05$} \\
\hline & Con & $36.48 \pm 3.88$ & \\
\hline
\end{tabular}

There was no statistically significant differences between experimental and control group in mean of age, husband's age, marriage duration and treatment duration $(p>.05)$. All of participants have graduate 
education. Neither the participants nor their husbands suffered from any other underlying disease. The mean and standard deviation of quality of life and anxiety scores divided by experimental and control group presented in Table 3.

Table 3

Means and standard deviation of variables divided by experimental and control groups

\begin{tabular}{|lllllllll|}
\hline Variables & \multicolumn{3}{l}{ Experimental group } & \multicolumn{3}{c|}{ Control group } \\
\cline { 2 - 9 } & Pre test & \multicolumn{2}{c}{ Post test } & Pre test & \multicolumn{3}{c|}{ Post test } \\
\cline { 2 - 10 } & Mean & SD & Mean & SD & Mean & SD & Mean & SD \\
\hline $\begin{array}{l}\text { Quality of life (total } \\
\text { score) }\end{array}$ & 208.97 & 43.64 & 235.65 & 31.59 & 209.81 & 42.69 & 203.32 & 41.93 \\
\hline Physical health & 41.08 & 8.51 & 46 & 5.96 & 41.25 & 8.1 & 40.08 & 8.79 \\
\hline Social Relationships & 32.5 & 9.68 & 36.75 & 7.39 & 32.58 & 9.17 & 31.75 & 9.56 \\
\hline Emotional health & 13.83 & 3.43 & 14.66 & 4.07 & 14.16 & 3.27 & 13 & 3.46 \\
\hline Mental health & 65.41 & 16.5 & 78.91 & 11.98 & 66.41 & 15.61 & 66.33 & 14.74 \\
\hline Economic & 16.08 & 2.39 & 16.25 & 2.45 & 16.08 & 2.46 & 16.08 & 2.46 \\
\hline Sexual Satisfaction & 14.66 & 4.53 & 16.25 & 3.59 & 13.83 & 4.72 & 13.75 & 4.78 \\
\hline Spiritual and religious & 25.41 & 3.82 & 26.83 & 3.01 & 25.5 & 4.12 & 25.33 & 4.14 \\
\hline Anxiety & 21 & 7.71 & 14.33 & 5.85 & 21.16 & 6.95 & 22.16 & 7.46 \\
\hline
\end{tabular}

As shown in Table 3, the mean scores of quality of life and anxiety in the pre-test phase are almost equal in the two groups, but in the post-test phase, the mean scores of the experimental group are different. Independent t-test showed that the mean scores of quality of life and anxiety in the pre-test phase was almost equal in the two groups ( $p>.05$ ). For hypothesis test, multivariate analysis covariance (MANCOVA) was conducted. Before the analysis, the assumptions of MANCOVA were examined. The results of Shapiro-Wilk test showed that the distribution of anxiety scores in the pre-test $(W=.92, P=.08)$ and post-test $(\mathrm{W}=.37, \mathrm{P}=.95)$, as well as distribution of total score of quality of life in pre-test $(\mathrm{W}=.94, \mathrm{P}$ $=0.29)$ and post-test $(W=.98) P=.61)$ was normal. The equality of variances of groups was assumed using the levene's test. The results showed that variance of experimental and control groups in the pretest $(F=.21, p=.64)$ and post-test $(F=1.26, P=.26)$ for anxiety and in the pre-test $(F=.01, P=.95)$ and post-test $(F=.72, P=.41)$ for quality of life is equal. Finally, regression slope homogeneity for the anxiety scores $(F=4.28, p=.06)$ and the quality of life $(F=.72, P=.41)$ were not violated. The research hypotheses was "self-compassion intervention based on a religious perspective has a significant effectiveness on the anxiety and quality of life of infertile women". Because the hypothesis has two dependent variables and there was possibility of their interference with each other, multivariate analysis covariance was used. MANCOVA was statistically significant $(F=60.22, p<.001)$ which indicate that selfcompassion intervention based on a religious perspective led to a significant change in the anxiety and 
quality of life scores of experimental group in the post test phase. Partial $\eta^{2}$ showed that $86 \%$ of the variance changes in the anxiety and quality of life in the experimental group can be attributed to selfcompassion intervention. Test of between subjects in MANCOVA was used to determine which of the dependent variables was significantly changed. The results showed that both anxiety $(F=68.54, P<.001$, Partial $\left.\eta^{2}=.77\right)$ and quality of life $\left(F=57.22, P<.001\right.$, Partial $\left.\eta^{2}=.74\right)$ significantly decreased and increased, respectively, after the intervention.

The MANCOVA test was used again to examine statistical changes in the subscales of quality of life after the intervention. The results showed that self-compassion intervention led to changing scores of at least one subscales of the quality of life in experimental group $\left(F=5.85, P<.01\right.$, Partial $\left.\eta^{2}=.82\right)$. Test of between subjects in MANCOVA showed that physical $\left(F=20.01, P=.001\right.$, Partial $\left.\eta^{2}=.57\right)$, emotional $(F=$ $6.66, P=.002$, Partial $\left.\eta^{2}=.31\right)$, social $\left(F=14.43, P=.02\right.$, Partial $\left.\eta^{2}=.49\right)$, Mental $(F=32.45, P=.001$, Partial $\left.\eta^{2}=.68\right)$, sexual $\left(F=7.04, P=.01\right.$, Partial $\left.\eta^{2}=.32\right)$ and spiritual and religious $(F=6.01, P=.02$, Partial $\eta^{2}=.28$ ) dimensions of quality of life were statistically changed in experimental group after the intervention. But, economic dimensions of quality of life was not statistically changed after the selfcompassion intervention in experimental group $\left(F=.59, P=.45\right.$, Partial $\left.\eta^{2}=.03\right)$.

\section{Discussion}

The results of this study indicate that self-compassion intervention based on a religious perspective has a significant effect on improving the quality of life of infertile women. This finding is consistent with previous studies that indicate individuals with high self-compassion have higher quality of life indicators such as psychological satisfaction, self-efficacy, independence, purpose in life, personal development, happiness and optimism $[12,15,20,24-26]$.

However, these studies either investigated compassion without integrating with religious instructions [12] or merely reviewed compassion and religion without examining its effectiveness [15]. As mentioned previously, only one study has so far incorporated self-compassion intervention and Islamic teachings [18]; although its findings confirmed the effectiveness of this intervention, the study carried out on cancer patients and the dependent variable was self-compassion.

It seems that, self-compassion intervention has improved infertile women quality of life, mostly by changing their attitudes toward infertility, which is something beyond their control; at the same time, the infertile women got a positive view of her conditions and hope for the effectiveness of her treatment [26]. Because infertile women may feel more isolated from their peers, the social dimension of their quality of life may decline [3]. Self-compassion can help infertile women to feel that they are not alone in their problem and that there are others who are infertile or suffer from irreversible problems such as having a disabled child (common humanity dimension). Therefore, instead of blaming themselves, they tend to be kind to themselves and look at themselves with a non-judgment view (Self-kindness dimension) [25]. 
Infertile women find that, despite their efforts to purist of treatment, the attitude of the others has not been changed. However, a woman with high self-compassion come to the conclusion that the behavior of others is not because of her problem but because of the sympathy they may have with her. In fact, empathy with others, which is a component of self-compassion, leads to this attitude in infertile women and improve their kindness toward others [27]. Consequently, by reducing self-blame and blaming others, their quality of life may increase.

The findings of this study showed that self-compassion intervention based on a religious perspective could reduce the anxiety of infertile women. This finding is in line with previous studies $[20,25,28,29]$. It seems that many of the problems that infertile women have in adjustment are due to the difficulty in emotion regulating [29]. Self-compassion may serve as an emotional regulation strategy and increase the resilience of infertile women in dealing with self-blame [25]. Mostly, negative affects in infertile women are due to their self-criticism and self-judgment. So, self-compassionate attitude may function as a form of resiliency against the negative influence of self-criticism and social blame toward infertile women [29]. Evidences show that self-compassion serve as a buffer against the negative consequences of shame and guilt and self-blame in infertile women and significantly predict anxiety and depression in them $[28,29]$.

In compassion intervention sessions, infertile women were consciously reviewing their suffering in life with a compassion manner and by self-forgiveness they attained spiritual and physical relaxation. They found true peace in closing to God and accepting their destiny, while to and their situation and accept responsibility for their lives. On the other hand, according to serenity prayer, they worship as follow: "God, grant me the serenity to accept the things I cannot change, the courage to change the things I can, and the wisdom to know the difference". The acceptance and commitment which receive through this exercise will help them manage stress and reduce psychological stress [30].

Although the role of self-compassion in improving the quality of life of other diseases such as celiac disease [31], cancer [32], HIV [33], persistent musculoskeletal pain [34] and chronic disease management [35] has been acknowledged, but as confirmed in cancer patients [18], religious implications can be added to increase the effectiveness of self-compassion intervention, especially in a country, such as Iran, with a religious cultural background.

Islam regards compassion as a concept that is close to human nature and resulted in human being's happiness and tranquility. Not harming oneself and others is one of the key components of compassion in Islam [36]. Sometimes people can also harm themselves with inappropriate thoughts, stress and anxiety. Therefore, a person who has a religious self-compassion avoids the thoughts that lead to anxiety, which reduces anxiety and enhances his quality of life.

\section{Conclusion}

Findings of the study showed that self-compassion focused intervention enriched by Islamic instructions could significantly improve quality of life and anxiety of infertile women. Therefore, in order to improve the quality of life of infertile women and consequently for better effectiveness of medical treatments, it is 
suggested to adopt a self-compassionate approach based on Islamic teachings for infertile women in infertility clinics. An infertile woman must first accept her problem in order to be able to avoid self-blame and tend to self-kindness. Regarding, in this study, religious instruction was used alongside compassionate treatment because it could be helpful for acceptance of the infertility. When one accepts God's kindness toward herself and other universes, she considers events in her life, whether positive or negative, as part of God's will. As a result, the kindness of God extends to the self-kindness and promotes self-compassion. In Islamic beliefs, life is hard and difficult, and everyone has a problem in their lives. Problems cause one to always feel the presence of God in her/his and make life valuable. Alongside suffering, life becomes valuable. The two dimensions of self-compassion, empathy with self and others and common humanity, are exactly in line with Islamic teachings. Therefore, if a person has a religious background, combining compassionate treatment and religious doctrine can help make compassion treatment more effective.

\section{Limitations And Future Research}

Although self-compassion intervention was enriched with Islamic instructions, but due to the lack of a comparative group that merely evaluates the effectiveness of a compassionate intervention without integrating with religious concepts, it cannot certainly conclude that improvement in quality of life and anxiety in the experimental group was related to religious enrichment or that the self-compassion intervention alone was effective. Due to executive limitations, there was no comparison group in this study that received only self-compassion intervention, so it is recommended that future studies replicate this intervention with the comparison group. In this study, it was assumed that religion can help infertile women accept the problem and increase their self-compassion, and therefore its incorporation into selfcompassion therapy can be helpful. However, other interventions such as the acceptance and commitment approach have the same default. So it is recommended that in future studies, selfcompassion intervention enriched by religious instructions be compared with intervention enriched by acceptance and commitment therapy.

\section{Abbreviations}

QOLICQ: Quality of Life Questionnaire in Infertile Couples Questionnaire; BDI: Beck anxiety inventory; MANCOVA: multivariate analysis covariance;

\section{Declarations}

\section{Acknowledgments}

We thank all the students participated in the study.

\section{Authors' contributions}


Y R-M participated in study design, review of the literature, data collection, and data analysis. FA participated in data collection. RA participated in review of the literature and managed fieldwork. AC, SM, LS monitored and revised the manuscript. All authors read and approved the final manuscript.

\section{Funding}

The author(s) received no financial support for the research, authorship, and/or publication of this article

\section{Availability of data and materials}

Data and materials are confidential and will be available upon reasonable request $f$ rom the corresponding author

\section{Ethics approval and consent to participate}

The study objectives were explained to the participants and before the intervention they were given a draft of the intervention program. Participants were asked to read and sign the consent form consciously. Ethical consent was obtained from Kazerun Islamic Azad University research committee (Approval ID: IR.IAU.KAU.REC.1398.054). Considering the research ethics, after the study, the intervention also was presented to the control group.

\section{Consent for publication}

Not applicable.

\section{Competing interests}

The authors have no conflicts of interest to state.

\section{References}

1. ICMART obo, WHO Zegers-Hochschild F, Adamson GD, de Mouzon J, Ishihara O, Mansour R, Nygren K, Sullivan E, van der Poel S. ICMART obo, WHO: The International Committee for Monitoring Assisted Reproductive Technology (ICMART) and the World Health Organization (WHO) Revised Glossary on ART Terminology, 2009. Hum Reprod 2009, 24:2683-2687.

2. Salih Joelsson L, Tydén T, Wanggren K, Georgakis MK, Stern J, Berglund A, Skalkidou A. Anxiety and depression symptoms among sub-fertile women, women pregnant after infertility treatment, and naturally pregnant women. Eur Psychiatry. 2017;45:212-9.

3. Greil AL, Slauson-Blevins K, McQuillan J. The experience of infertility: a review of recent literature. Sociol Health IIIn. 2010;32:140-62.

4. Chiaffarino F, Baldini MP, Scarduelli C, Bommarito F, Ambrosio S, D'Orsi C, Torretta R, Bonizzoni M, Ragni G. Prevalence and incidence of depressive and anxious symptoms in couples undergoing 
assisted reproductive treatment in an Italian infertility department. Eur J Obstet Gynecol Reprod Biol. 2011;158:235-41.

5. Maroufizadeh S, Ghaheri A, Almasi-Hashiani A, Mohammadi M, Navid B, Ezabadi Z, Omani Samani $\mathrm{R}$. The prevalence of anxiety and depression among people with infertility referring to Royan Institute in Tehran, Iran: A cross-sectional questionnaire study. Middle East Fertil Soc J. 2018;23:103-6.

6. Hoff HS, Crawford NM, Mersereau JE. Screening for Psychological Conditions in Infertile Women: Provider Perspectives. J Women's Health. 2018;27:503-9.

7. Rooney KL, Domar ADJCOiO. The impact of stress on fertility treatment. Curr Opin Obstet Gynecol. 2016;28:198-201.

8. Neff KD, Kirkpatrick KL, Rude SS. Self-compassion and adaptive psychological functioning. J Res Pers. 2007;41:139-54.

9. Macaskill A. Exploring religious involvement, forgiveness, trust, and cynicism. Ment Health Relig Cult. 2007;10:203-18.

10. Neff K. Self-Compassion: An Alternative Conceptualization of a Healthy Attitude Toward Oneself. Self Identity. 2003;2:85-101.

11. Yarnell LM, Neff KD. Self-compassion, Interpersonal Conflict Resolutions, and Well-being. Self Identity. 2013;12:146-59.

12. Ebrahimifar M, Hosseinian S, Saffariyan Tosi MR, Abedi MR. To Compare of the Effectiveness of training based on "Acceptance and Commitment Therapy" and "Compassion Focused Therapy" on Self-efficacy, Quality of Relations and Meaning in Life in Infertile Women. J Health Promot Manag. 2019;8:10-8.

13. Kirby JN, Tellegen CL, Steindl SR. A Meta-Analysis of Compassion-Based Interventions: Current State of Knowledge and Future Directions. Behav Ther. 2017;48:778-92.

14. Arch JJ, Brown KW, Dean DJ, Landy LN, Brown KD, Laudenslager ML. Self-compassion training modulates alpha-amylase, heart rate variability, and subjective responses to social evaluative threat in women. Psychoneuroendocrinology. 2014;42:49-58.

15. Ghorbani N, Watson PJ, Chen Z, Norballa F. Self-Compassion in Iranian Muslims: Relationships With Integrative Self-Knowledge, Mental Health, and Religious Orientation. Int J Psychol Relig. 2012;22:106-18.

16. Shepperd JA, Miller WA, Smith CT. Religiousness and aggression in adolescents: The mediating roles of self-control and compassion. Aggress Behav. 2015;41:608-21.

17. Engineer AA. On the concept of compassion in Islam. Mumbai: Centre for the Study of Society and Secularism; 2001.

18. Shahedpour A, Hatami M, Noury R, Borjali M. Comparing the efficacy of compassionate therapy adapted to islamic teachings with compassionate therapy on self-compassion of breast cancer patients. J Psychol Sci. 2019;18:869-78. 
19. Jamshidian QalehShahi P, Aghaei A, Golparvar M. Comparing the Effect of Iranian Positive Therapy and Acceptance-Commitment Therapy on Depression, Anxiety and Stress of Infertile Women in Isfahan City. J Health Promot Manag. 2017;6:8-16.

20. Neff KD, Germer CK. A Pilot Study and Randomized Controlled Trial of the Mindful Self-Compassion Program. J Clin Psychol. 2013;69:28-44.

21. Yaghmaei F, Mohammadi S, Alavi Majd H. Developing and Measuring Psychometric Properties of "Quality of Life Questionnaire in Infertile Couples". IJCBNM. 2013;1:238-45.

22. Beck AT, Epstein N, Brown G, Steer RA. An inventory for measuring clinical anxiety: Psychometric properties. J Consult Clin Psychol. 1988;56:893-7.

23. Kaviani H, Mousavi AS. Psychometric properties of the Persian version of Beck Anxiety Inventory (BAI). Tehran Univ Med J. 2008;66:136-40.

24. Cunha M, Galhardo A, Pinto-Gouveia J. Experiential avoidance, self-compassion, self-judgment and coping styles in infertility. Sex Reprod Healthc. 2016;10:41-7.

25. Raque-Bogdan TL, Hoffman MA. The Relationship Among Infertility, Self-Compassion, and WellBeing for Women With Primary or Secondary Infertility. Psychol Women Q. 2015;39:484-96.

26. Shaukat J, Zafar N, Kausar R. Self-Compassion and positive psychological functioning in women with primary and secondary infertility. Bahria J Prof Psycho/ 2015, 14.

27. izadi n, sajjadian i. The Relationship between Dyadic Adjustment and Infertility-Related Stress: The Mediated Role of Self-compassion and Self-judgment. Iranian J Psych Nurs. 2017;5:15-22.

28. Galhardo A, Cunha M, Pinto-Gouveia J, Matos MJJoCPiMS. The Mediator Role of Emotion Regulation Processes on Infertility-Related Stress. J Clin Psychol Med S. 2013;20:497-507.

29. Pinto-Gouveia J, Galhardo A, Cunha M, Matos M. Protective emotional regulation processes towards adjustment in infertile patients. Hum Fertil. 2012;15:27-34.

30. Campbell EL. Utilizing the Serenity Prayer to Teach Psychology students about Stress Management. J Psychol Theol. 2015;43:3-7.

31. Dowd AJ, Jung ME. Self-compassion directly and indirectly predicts dietary adherence and quality of life among adults with celiac disease. Appetite. 2017;113:293-300.

32. Kearney KG, Hicks RE. Self-compassion and breast cancer in 23 cancer respondents: Is the way you relate to yourself a factor in disease onset and progress? Psychol. 2017;8:14-26.

33. Brion JM, Leary MR, Drabkin AS. Self-compassion and reactions to serious illness: The case of HIV. J Health Psychol. 2014;19:218-29.

34. Wren AA, Somers TJ, Wright MA, Goetz MC, Leary MR, Fras AM, Huh BK, Rogers LL, Keefe FJ. SelfCompassion in Patients With Persistent Musculoskeletal Pain: Relationship of Self-Compassion to Adjustment to Persistent Pain. J Pain Symptom Manag. 2012;43:759-70.

35. Sirois FM, Rowse G. The role of self-compassion in chronic illness care. J Clin Outcomes Manag. 2016;23:521-7. 
36. Alharbi J, Al Hadid L. Towards an understanding of compassion from an Islamic perspective. J Clin Nurs. 2019;28:1354-8.

\section{Figures}

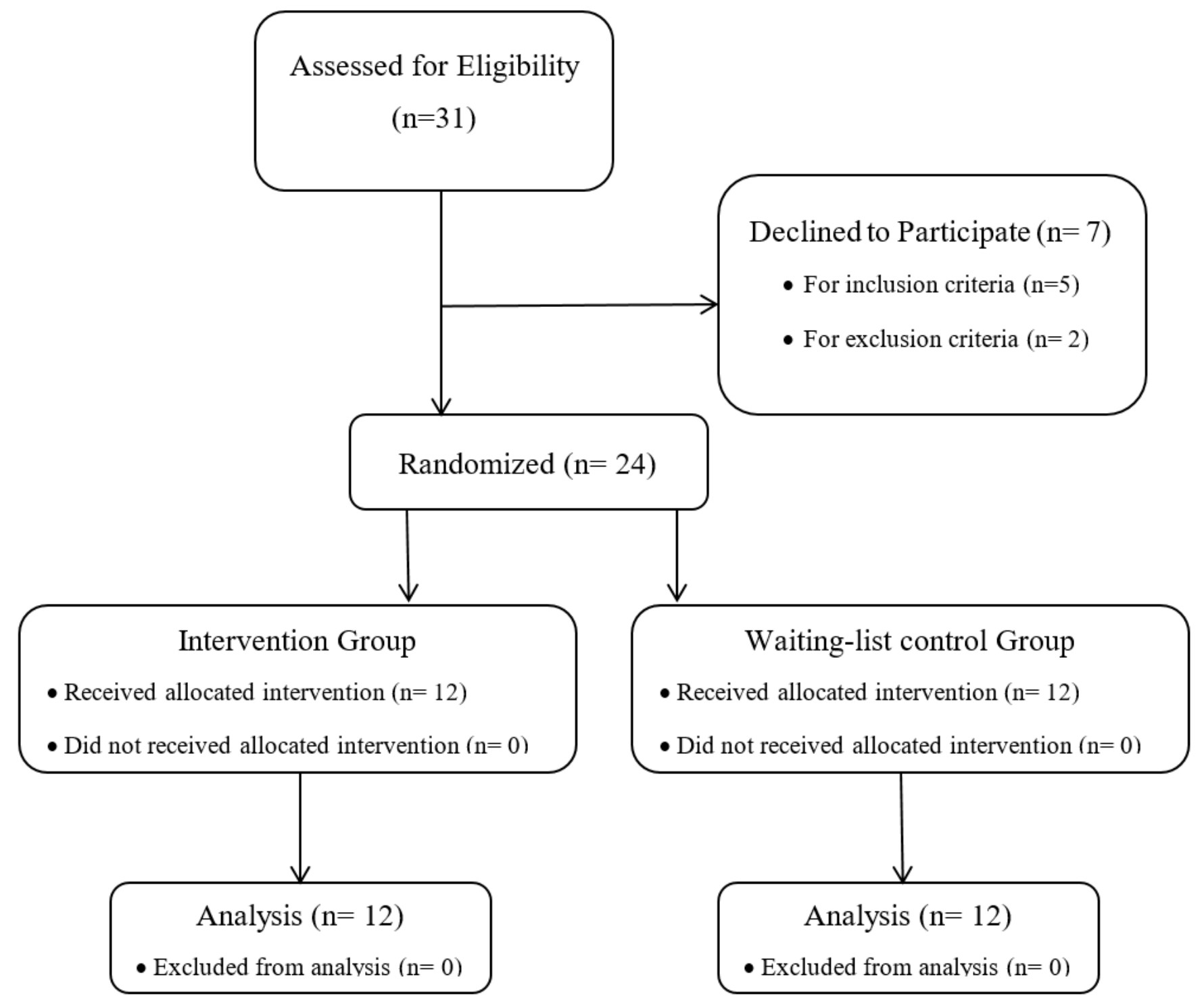

Figure 1

Intervention flow-chart

\section{Supplementary Files}

This is a list of supplementary files associated with this preprint. Click to download.

- STROBEchecklistcrosssectional.docx 